University of Nebraska - Lincoln

DigitalCommons@University of Nebraska - Lincoln

Textile Society of America Symposium Proceedings

Textile Society of America

2018

Fish in the desert - North Africa's textile tradition between indigenous identity and exogenous shifts in meaning

Silvia Dolz

Follow this and additional works at: https://digitalcommons.unl.edu/tsaconf

Part of the Art and Materials Conservation Commons, Art Practice Commons, Fashion Design Commons, Fiber, Textile, and Weaving Arts Commons, Fine Arts Commons, and the Museum Studies Commons

This Article is brought to you for free and open access by the Textile Society of America at DigitalCommons@University of Nebraska - Lincoln. It has been accepted for inclusion in Textile Society of America Symposium Proceedings by an authorized administrator of DigitalCommons@University of Nebraska - Lincoln. 


\section{The Social Fabric: Deep Local to Pan Global}

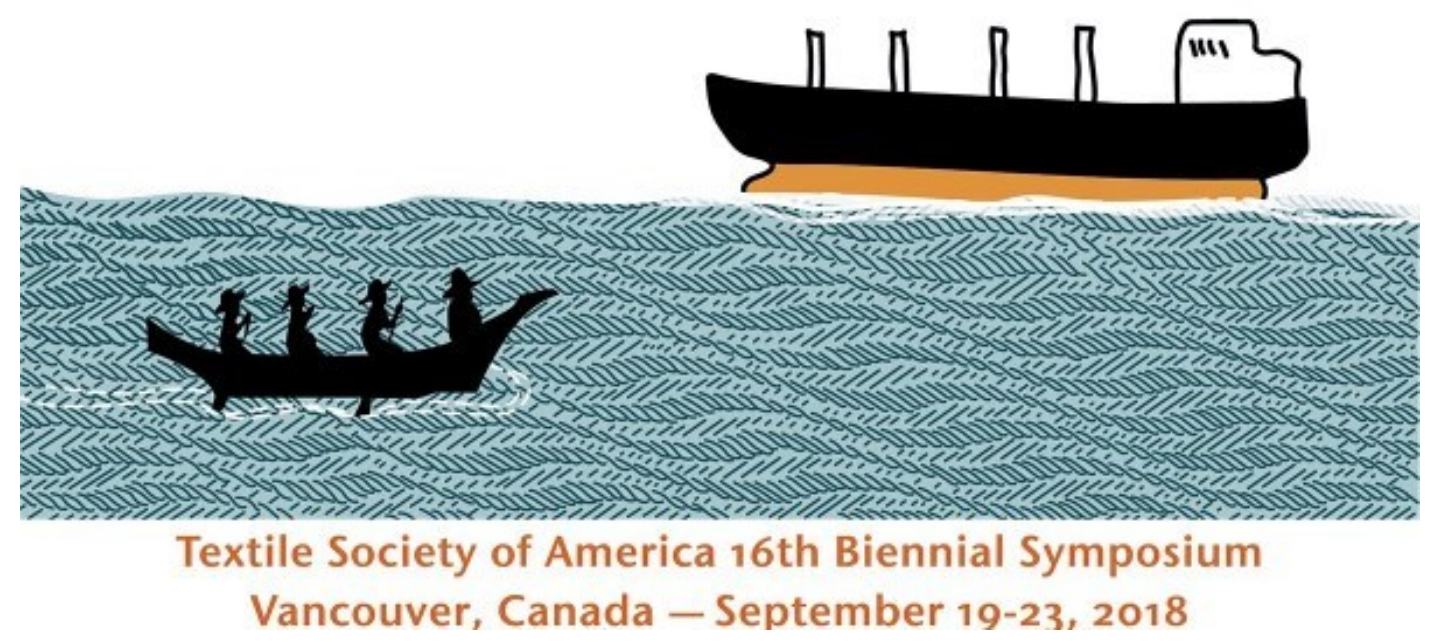

Published in Textile Society of America Symposium Proceedings 2018

Presented at Vancouver, BC, Canada; September 19 - 23, 2018

https://digitalcommons.unl.edu/tsaconf/

Copyright $@$ by the author(s). 


\title{
Fish in the desert - North Africa's textile tradition between indigenous identity and exogenous shifts in meaning
}

\author{
Silvia Dolz \\ silvia.dolz@skd.museum
}

Nowadays, even people living in remote areas are experiencing changes to their lives that are not only radical and far-reaching but are also occurring at an ever faster pace. In these regions, as elsewhere, the need to adapt to new economic and living conditions, obligatory school attendance, satellite television, the internet, tourism and the ubiquitous availability of mostly imported industrial products shapes people's needs and desires, while also influencing their aspirations and values. Not only in the urban centres of North Africa, but also in the mountain villages and oases, ancient knowledge seems to be disappearing and the interest of young people in their local traditions is fading away. Even in those places where the most important North African handicraft sector - the knotting, weaving and embroidering of textile fabrics - is still being passed on to the younger generation by grandmothers and mothers, the techniques and patterns, and the meanings associated with them, are undergoing change. The altered living conditions, the different sources of income and new educational structures result in people producing fewer and fewer carpets, blankets or clothing for their own use. Around the mid- $20^{\text {th }}$ century, the female-dominated domestic craft industry of Tunisia and Morocco saw an increasing trend towards market production. The state co-operatives that were established in many rural areas during that period succeeded in ensuring the preservation of local handicraft traditions, but owing to the regulation, standardisation and commercialisation of their products under the auspices of the Offices nationaux de l'Artisanat, which introduced state-approved quality seals, they left little scope for vitality and authenticity in the textiles created. ${ }^{1}$

It is such authentic textiles that will be considered here. They are textiles steeped in tradition, suffused with historical references, fulfilling changed functions, and they are, above all, textiles possessing baraka, a force of blessing. Ultimately, all these factors mean that each of these individually made products is a component in a complex, religiously reflective world view and global context.

Upon closer observation, it is clear that continuity and change are always interconnected, and that those life strategies and life journeys are successful in which traditions do not 'congeal' but develop in an innovative way. It is equally evident that radical breaks with history and traditions can lead to a sense of rootlessness and a feeling that the material world, and earthly existence itself, has lost its soul. Finally, we can also observe the fascinating process through which these textile creations "become art" within the broader semantic framework of the

\footnotetext{
${ }^{1}$ Silvia Dolz, Produkte des textilen Frauenhandwerks aus Tunesien im kulturellen und historischen Vergleich, Abhandlungen und Berichte des Staatlichen Museums für Völkerkunde Dresden, 50 (1999), 23. Abdelkebir Khatibi and Ali Amahan, From Sign to Image: The Moroccan Carpet (Casablanca: Lak International Edition, 1995), 28.
} 
Western or European concept of art and in a completely open culture-historical and geographical environment.

Today, we are vaguely aware that the cultural diversity of the Maghreb is based on very old knowledge traditions, which have continually incorporated innovative technical and material developments and intellectual ideas. Yet we have merely fragmentary knowledge of the specific ways in which this transfer has taken place. This not only applies to what is presumably the oldest settlement layer dating back to the Garamantes, Numidians and Libyans (c.3000 BCE), who are regarded as the ancestors of the population group known today as "Berbers." It is equally true as regards the Phoenician-Carthaginian $\left(11^{\text {th }}-2^{\text {nd }}\right.$ cent. $\mathrm{BCE}$ ) and Roman civilisations $\left(2^{\text {nd }}\right.$ cent. $\mathrm{BCE}-5^{\text {th }}$ cent. $\mathrm{CE}$ ), and even to the Islamic era (since the $7^{\text {th }}$ cent. $\mathrm{CE}$ ), which is not only associated with a religious doctrine but is also a major sociocultural factor. Over the past 1300 years of the Islamic period alone, the Maghreb has been influenced by the very diverse cultural features of the Arab (Kharijites $8^{\text {th }}-10^{\text {th }}$ cent., Aghlabids $9^{\text {th }}-10^{\text {th }}$ cent., Fatimids $10^{\text {th }}-12^{\text {th }}$ cent. $)$, the Berber Almoravid $\left(11^{\text {th }}-12^{\text {th }}\right.$ cent.), Almohad (12 $2^{\text {th }}-13^{\text {th }}$ cent. $)$ and Marinid $\left(13^{\text {th }}-15^{\text {th }}\right.$ cent. $)$, the Moorish-Andalusian $\left(13^{\text {th }}-15^{\text {th }}\right.$ cent.) and the Turkish-(Anatolian)-Ottoman $\left(15^{\text {th }}-19^{\text {th }}\right.$ cent.) periods in the Maghreb. The graphic symbols of an ancient Libyan script, which later developed into Tifinagh, the alphabet of the Imazighen, survived into the modern era. ${ }^{3}$ The Jews who settled in North Africa from the $1^{\text {st }}$ century CE onwards brought their own religious symbolism with them. ${ }^{4}$ Traces were also left by Christian Byzantium under Emperor Justinian ( $6^{\text {th }}$ century), resulting in Greek and Coptic cultural elements. Contacts between north-western Africa and the regions south of the Sahara date back as far as the $5^{\text {th }}$ century BCE, intensified with the expansion of trans-Sahara trade around the start of the Common Era, and led to intensive cultural exchange in the Islamic period. ${ }^{5}$ Finally, mention should also be made of European influence in the modern era, beginning with Portuguese and Spanish maritime trade (starting in the $15^{\text {th }}$ century) on the coasts of North Africa.

All these cultural phenomena left their traces, especially in North African textiles, one of the most important mobile material artefacts testifying to urban and rural culture over the centuries. What makes North African textiles such a precious cultural asset is not only their functional diversity: carpets and flat woven fabrics as floor coverings, seating mats or sleeping rugs, partition walls or even accommodation (nomad tents), prayer rugs and coverings for holy sites, ritual textiles associated with the circle of life (birthing sheets, wedding veils and death shrouds), bags (transportation and storage sacks), horse equipment (saddle blankets) and finally clothing. Their inestimable value lies in the stories that these textiles narrate through their motifs and patterns, which display an infinite range of compositions and colour variations, including pictograms and figures from many periods and all areas of life.

\footnotetext{
2 The foreign term "Berber" refers to an ethnic group in northern and north-western Africa that is both socially and culturally highly heterogeneous. These communities originally belonged to a single language family and are regarded as the indigenous population. They generally identify themselves as Imazighen (plural of Amazigh). Although islamicised, they have an important peculiarity: their religious tradition involves the veneration of local saints, a phenomenon known as maraboutism, which centres on old schools and tombs (called marabout or zawiya) associated with revered scholars and saints.

${ }^{3}$ Ibid.

${ }^{4}$ Angelika Tunis, Juden und Germanen im Maghreb al-Aqsa. In: Kurt Rainer, Marokko - mon amour. Glanzvolle Textil-Tradition im Königreich Marokko (Graz: Culture and more, 2005), 19-25.

${ }^{5}$ Christopher Spring and Julie Hudson, North African Textiles (London: British Museum Press, 1995), 11-25.
} 


\section{Life cycle and status}

The women of the Nafzawa oases in southern Tunisia produce shawls and cloaks for various periods of life which indicate the status of the wearer: as a young woman of marriageable age, as a bride during the wedding phase, as a mother, or as a revered elderly woman. Particularly colourful shawls with rich patterns incorporating individual ideas are used for the most important event in life - the wedding. The images symbolise change and transition, movement and rhythm, growth and balance. These emotions and conditions are reflected in (often narrative) design elements, such as certain compositions, symmetry and colour. Realistic individual motifs, and abstracted versions of them, in repeated geometric shapes have a high symbolic value as magical or ritual elements. They are bearers of baraka, the power of blessing. These include the "fish," "snake" and "scorpion," as well as the "hand" and "eye."

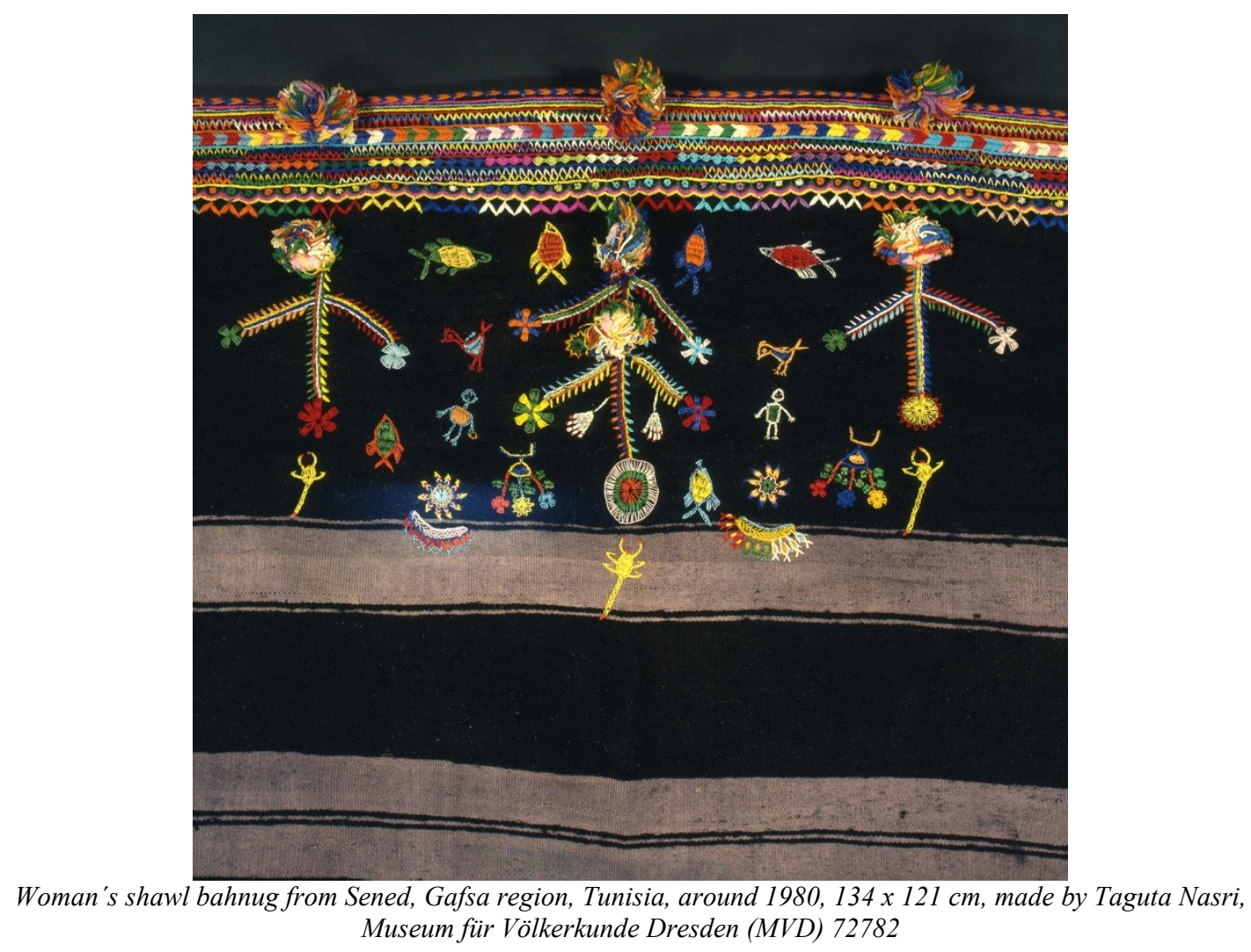

Such symbols are meant to protect against the "Evil Eye," i.e. envious looks and misfortune; they are a reminder of the constant presence of danger, chaos and struggle in life. Good fortune, prosperity and fertility, on the other hand, are associated with the "fish" or the (mostly eight-pointed) "star," and these powerful symbols are indispensable at weddings. The fish is associated with water, the essential elixir of life; like the star, it stands for growth and harmony in life. Thus, these two motifs are among the protective symbols known from prehistoric or pre-Islamic times throughout the Mediterranean region. ${ }^{6}$ Although it is fervently wished for at every wedding, motherhood is rarely depicted in the way it is on the carpet fragment produced by the Rehamna of Morocco. The rhythmic pattern of contractions

\footnotetext{
${ }^{6}$ Paul Vandenbroeck, Azetta - L'art des femmes berbères(Amsterdam, Bruxelles: Ludion Gand, 2000), 219. Edward Alexander Westermarck, Ritual and belief in Morocco (London: Macmillan and Co., 1926), vol.1: 64, 96, vol.2: 49, 252.
} 
during labour - represented by a series of lozenges - symbolises not only movement and change, but even creation of life itself. In the textile fabric, the weaver or knotter manifests her destiny and the structure of her life cycle.

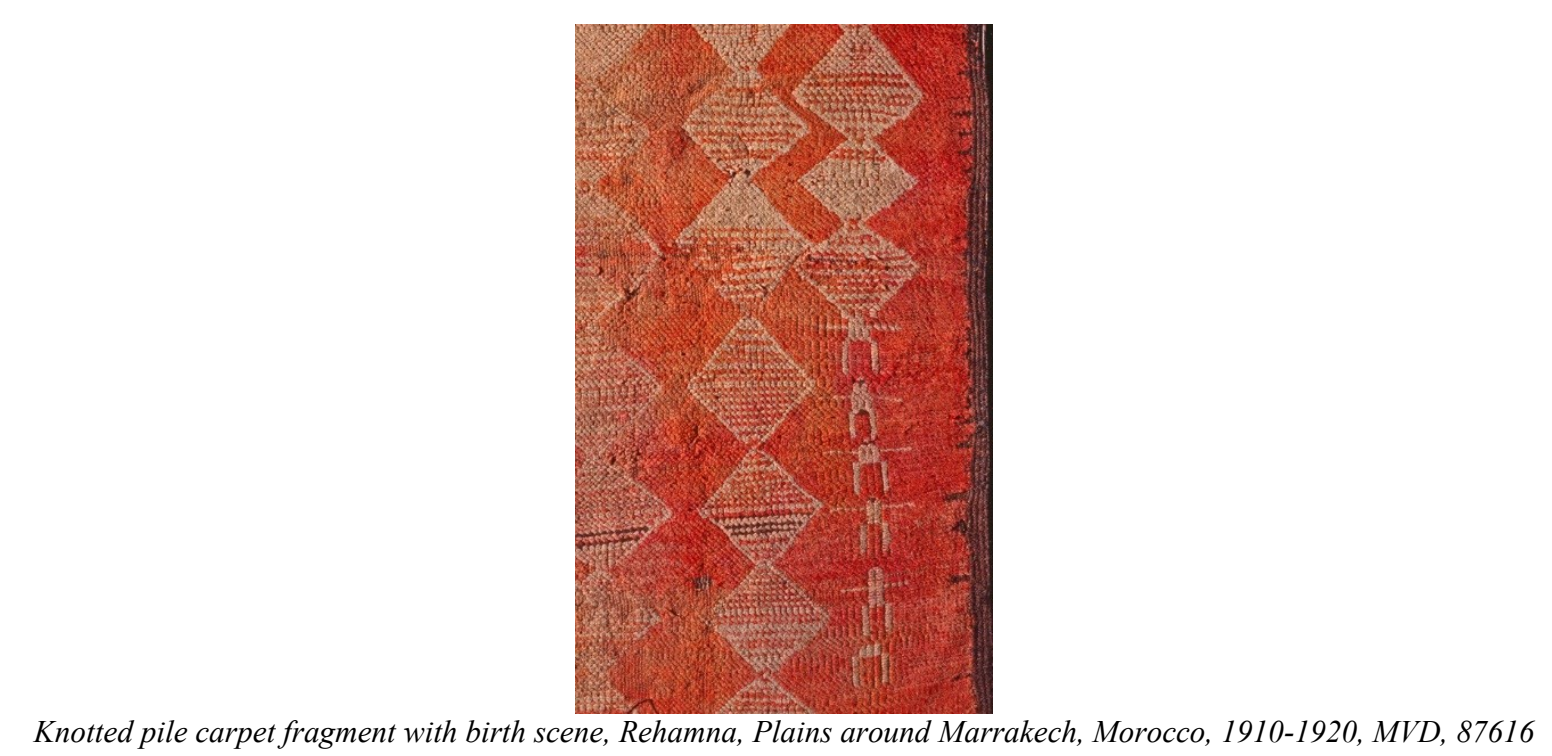

\section{Worldview and religiosity}

The textile becomes a testimony to a specific worldview in the context of divine mystery. Religiosity permeates all phases and aspects of life. The inexpressible is encoded in symbols. Through the repetition of motifs, an illusion is created and transcendence becomes tangible. The henna-painted shawls of the Feija in the central Anti-Atlas region of Morocco are used by the Chorfa, the descendants of saints, to concentrate baraka and achieve maximum protection. They are produced for the shrine of the marabout Beni Yâacoub in Imi n'Tatelt but are also sold from there. They seem to be painted quite intuitively with henna, the beneficial "herb of Paradise", and are worn by the bridal couple at every wedding. Motifs such as the "sandals of the Prophet," the "gate" $b a b$, "moon" and "star" constitute coded symbols which create a connection with the divine. ${ }^{7}$ Many of these symbols derive from preIslamic ideas and have a multicultural background. That which is ingrained in the collective consciousness as having proven useful and beneficial over long time periods is often continued in new social, political and religious contexts. For example, the $b a b$ symbol can be traced to an ancient Libyan or Tifinagh glyph corresponding to the letter "B."

\footnotetext{
${ }^{7}$ Annette Korolnik-Andersch and Marcel Korolnik, Die Farbe Henna. Bemalte Textilien aus Süd-Marokko (Stuttgart: Arnoldsche, Art Publishers, 2002), 39, 64-65, 68-110, 131-135.
} 

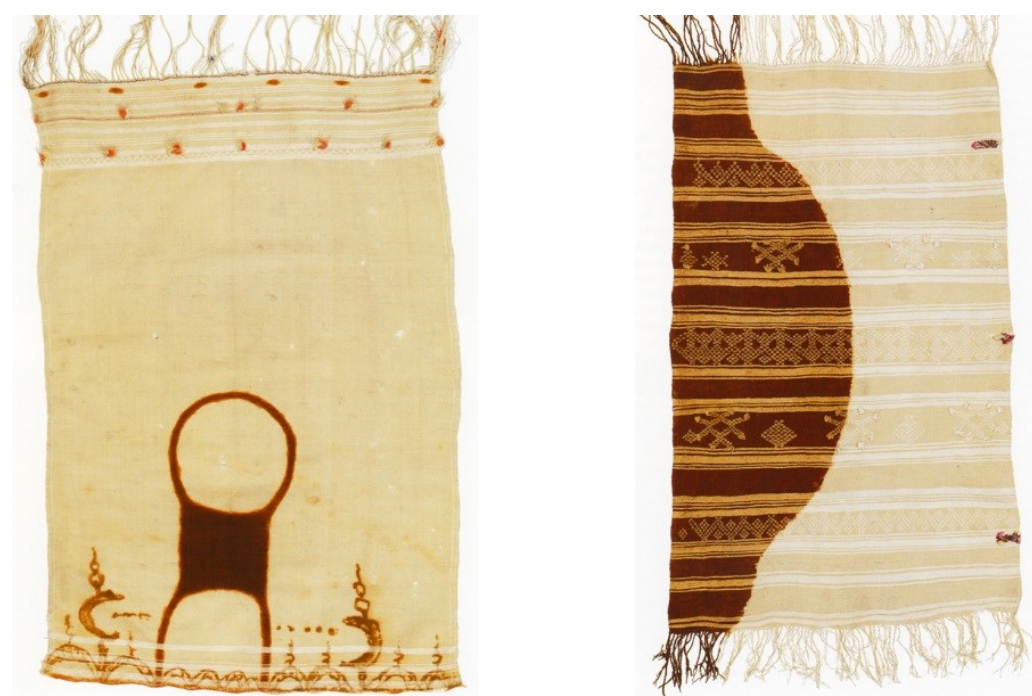

Left: Headscarf adrar with bab (gate) mofif, Erkoune, Feija area, Southern Morocco, around 1930, $118 x 66 \mathrm{~cm}$. Right: Headscarf adrar with itri (star) symbols, Imi n'Tatelt, Feija area, Southern Morocco, around 1930, $100 x 62 \mathrm{~cm}$ (both Collection Annette Korolnik)

\section{Orientation in life}

Contemplation and quiet provide orientation in life, which is also interpreted as spatial orientation. Edification, wellness and cheerfulness are associated with the Garden of Eden, but also with earthly gardens. This includes architecture (the dwelling house, the mosque, the $q u b b a$ or shrine), which demarcates a safe space.

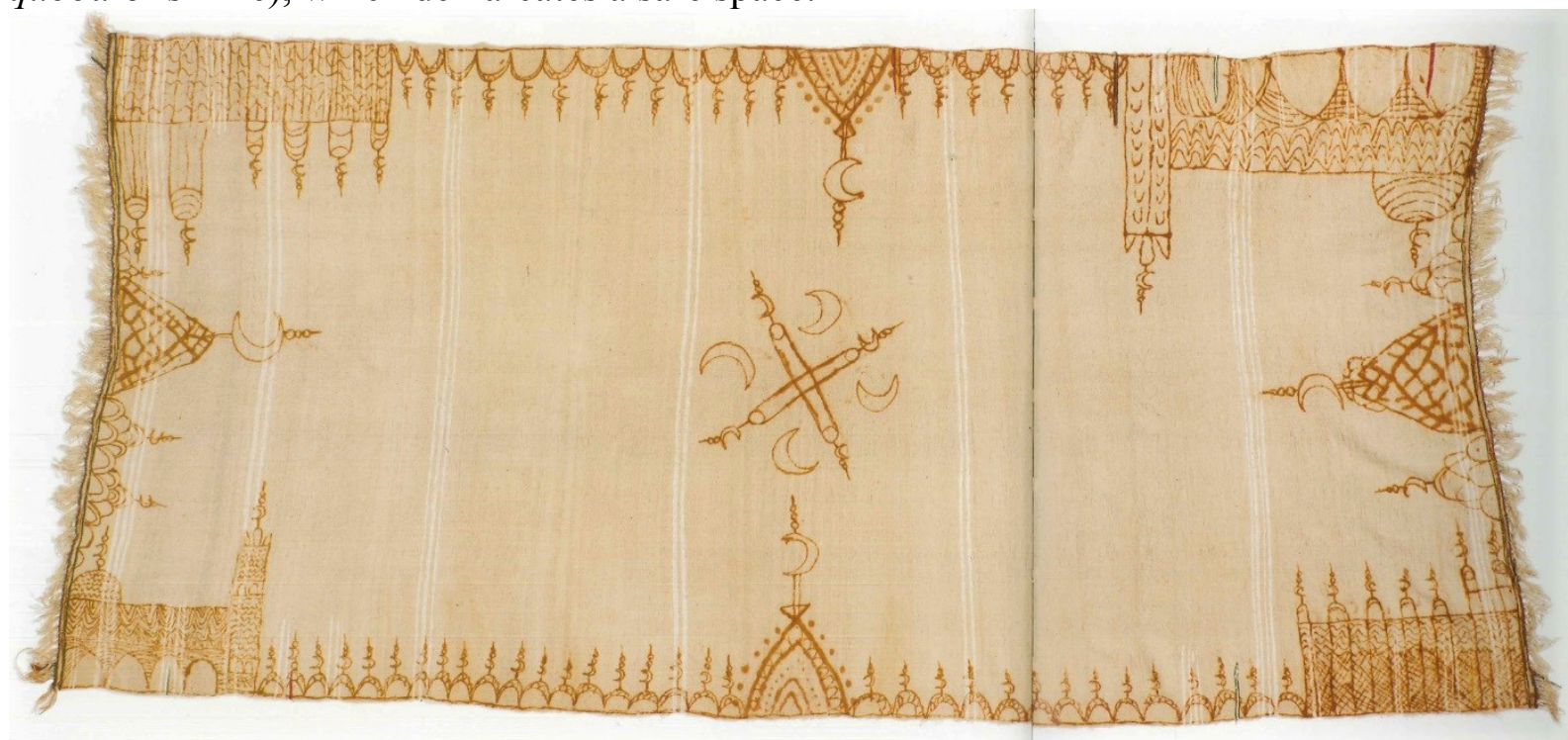

Wedding planket tahdicht, Erkoune, Feija area, Sothern Morocco, around 1950, 145 x 315 cm (Collection Annette Korolnik)

Design elements mostly incorporate symmetry or balance between composition and colours. Floral motifs, which are often derived from the eight-pointed star (originally based on the Seal of Solomon), the flower garden with pools and watercourses, the tree (the tree of life, date palm), birds and gazelles stand for harmony between culture and nature. 

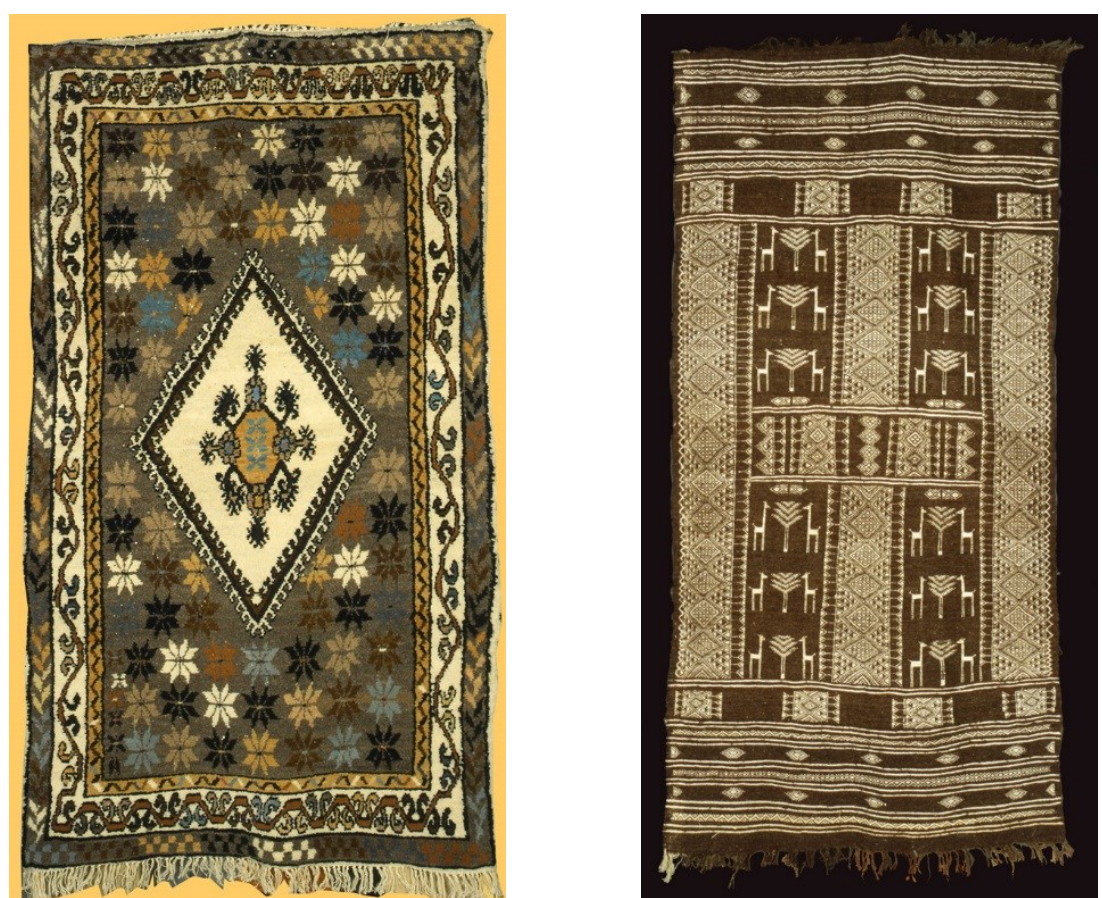

Left: Knotted pile carpets zarbiya with star or floral motifs (Jasmin flower), Gafsa, Tunisia, second half 20th cent., $232 \times 126 \mathrm{~cm}$, MVD 72879

Right: Flatwoven rug margum with patterns of gazelles, fish and tree of life, Tafertaset, Tunisia, around 1990, $222 \times 107 \mathrm{~cm}$, MVD 72781

\section{Beauty and aesthetic excellence}

Beauty and aesthetic excellence for the pleasure of God and as an incentive to stimulate the highest level of human creativity are evident in the "parade textiles" influenced by the Middle East. These are mostly knotted carpets intended for display, which were used by wealthy families and were laid out in mosques. With their hybrid floral and geometric symbols, they emphasise and exalt fundamental aspects of life, such as birth and death, marriage, the relationship between nature and culture, and divinity. Their designs feature frames and the careful structuring of patterns, as well as the balanced use of colours.

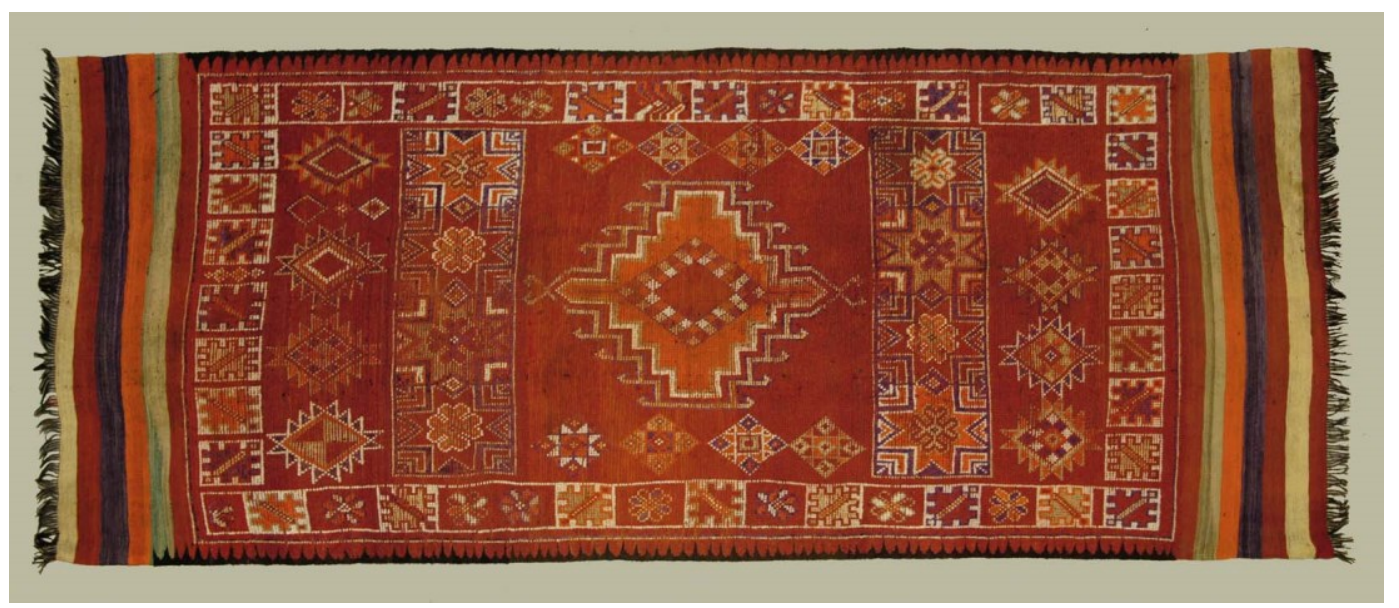

Knotted pile carpet with multicolored aprons, Chiadma or Oulad Bou Sbaa near Essaouira, Morocco, First quarter of $20^{\text {th }}$ cent., $363 \times 149 \mathrm{~cm}$, MVD 82738

\section{Individual creativity}

Individual creativity seems almost to burst out of some of these textile works. They are made in Morocco and Tunisia for the producers' own use. Some of the "wild" compositions show their makers to have given free rein to their imagination, experimenting with possibilities, 
taking risks and expressing their curiosity or simple joy in making them. Often several women would work together on one item as a social activity, chatting and joking and apparently letting things take their course, curious to see what the final result would look like.
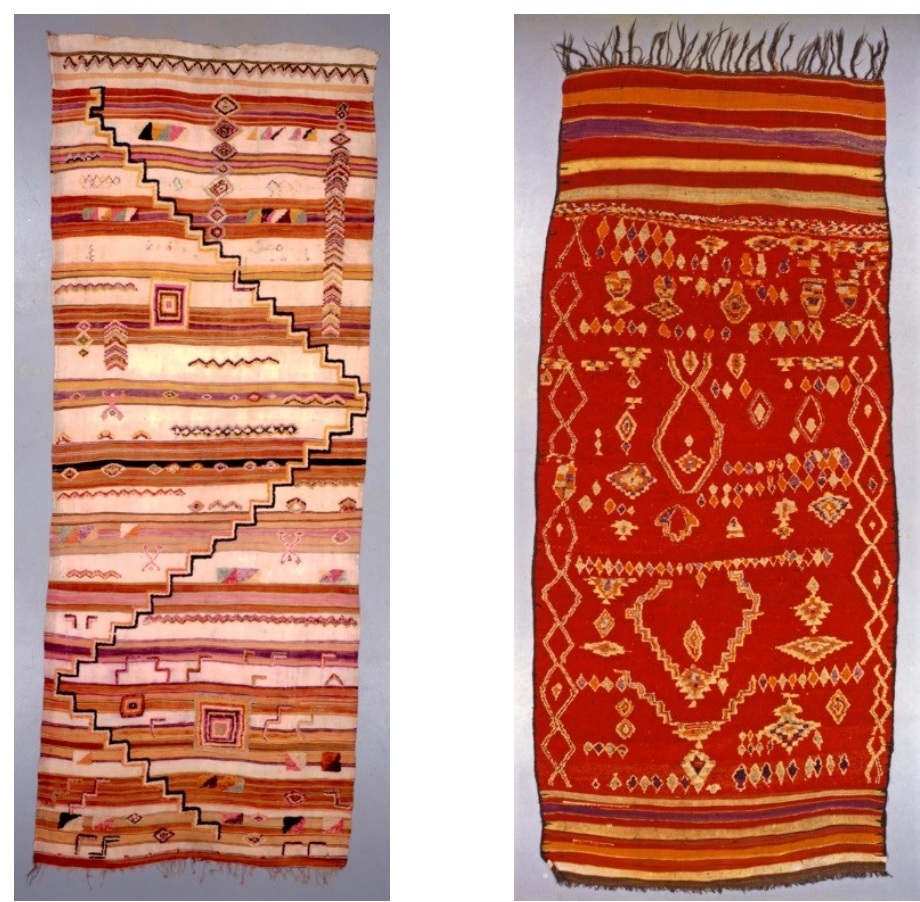

Left: Flatwoven rug with pieces of knotted pile, Rehamna, Morocco, 1940-1950, 166 x $435 \mathrm{~cm}$, MVD 82886 Right: Carpet, Rehamna, Plains around Marrakech, Haouz region, Morocco, early $20^{\text {th }}$ cent., collection Annette Korolnik

Abstract archetypal symbols are nearly always present. They concentrate magical powers and are known throughout all the different regions of North Africa as signs of protection (the "hand" with its symbolic meaning of "khamsa/five," "star," "eye/amulet"). The loss of meaning of certain signs and patterns is compensated for by local experiences of life and the environment. Thus, new symbols come into being, such as a coloured embroidered motif on the south Tunisian melhafa (a wrap-around robe worn by women) that can be identified as representing the footprints of desert animals in Sahara sand, or the Solomon's seal motif (star), which mutates into a jasmine blossom.

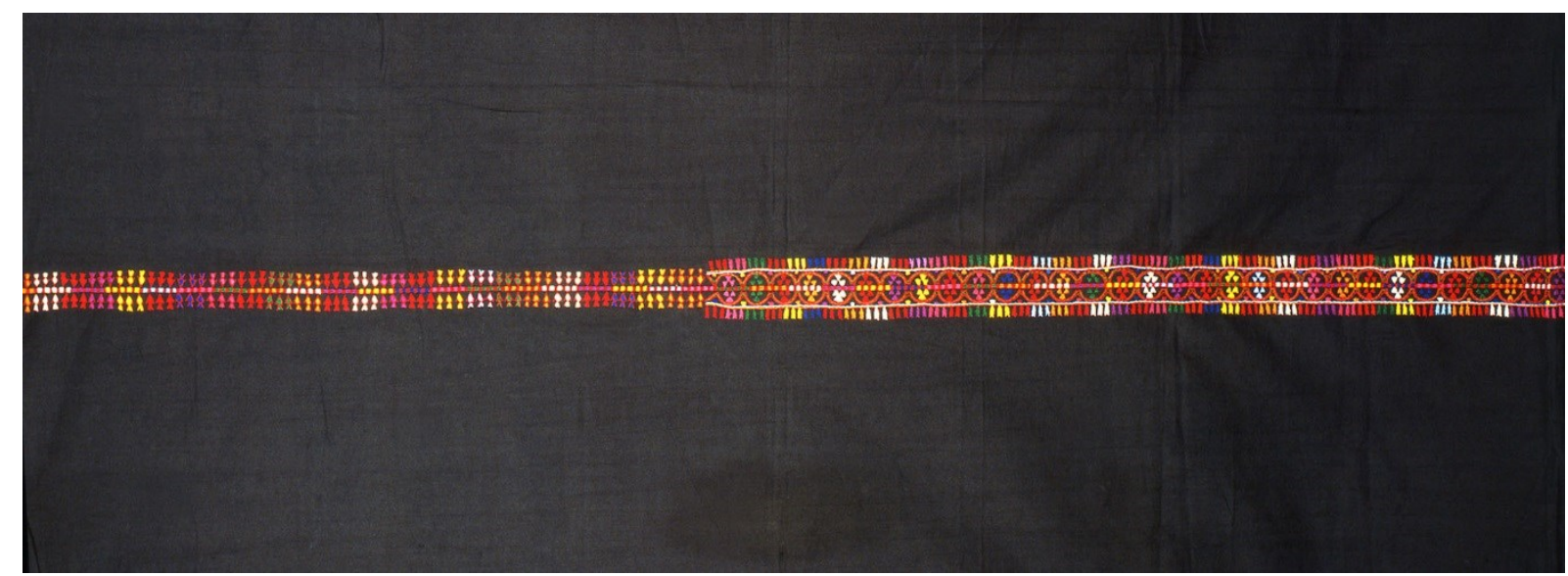

Woman's Robe melhafa with footprints of desert animals and fish motif, Marazig, Douz, Southern Tunisia, 1995, $396 \times 124 \mathrm{~cm}$, MVD 73725 
The old Tifinagh script symbol for " $Z$ " is turned into a dancer, or simply into the footprint of a dove, on a women's wrap-around robe worn by the Feija in Morocco. ${ }^{8}$

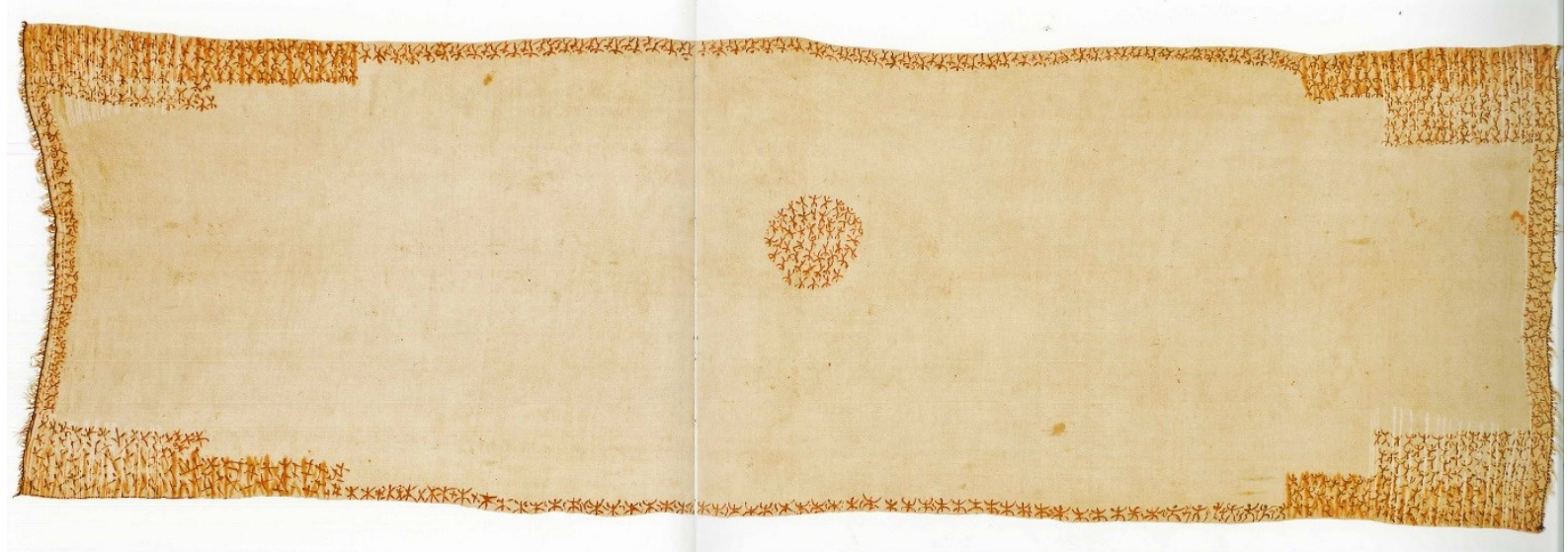

Woman's wrapper haik with dancing figures, Erkoune in Feija area, Southern Morocco, around 1900, $462 \times 147 \mathrm{~cm}$, Collection Annette Korolnik
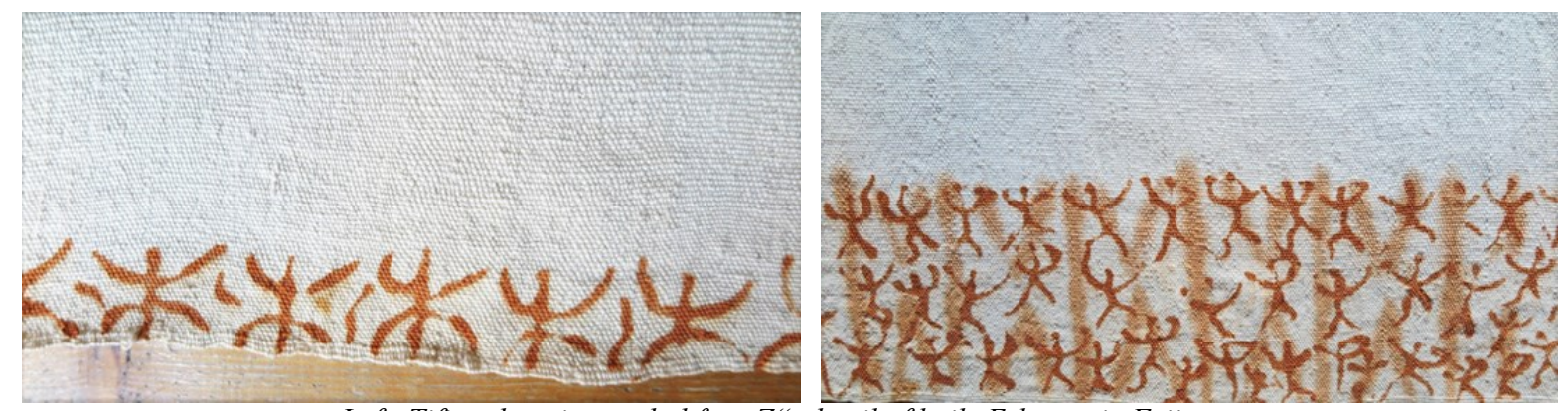

Left: Tifinagh script symbol for „Z“, detail of haik, Erkoune in Feija area Right: Dancing figures, detail of haik, Erkoune in Feija area

Another ancient Libyan symbol corresponding to the letter " $D$ " is transformed into a weaving comb, mschot, in south Tunisian textiles. The names given to many motifs can often be traced to animals, plants or objects that are familiar and useful, such as "camel," "palm," "corn," "scissors," "comb," or "tent."

\footnotetext{
${ }^{8}$ The representation of this modified symbol on the wedding robe is presumably a reference to the agoual, a dance of the Feija, Annette Korolnik-Andersch and Marcel Korolnik, Die Farbe Henna. Bemalte Textilien aus Süd-Marokko (Stuttgart: Arnoldsche, Art Publishers, 2002), 27, 105.
} 

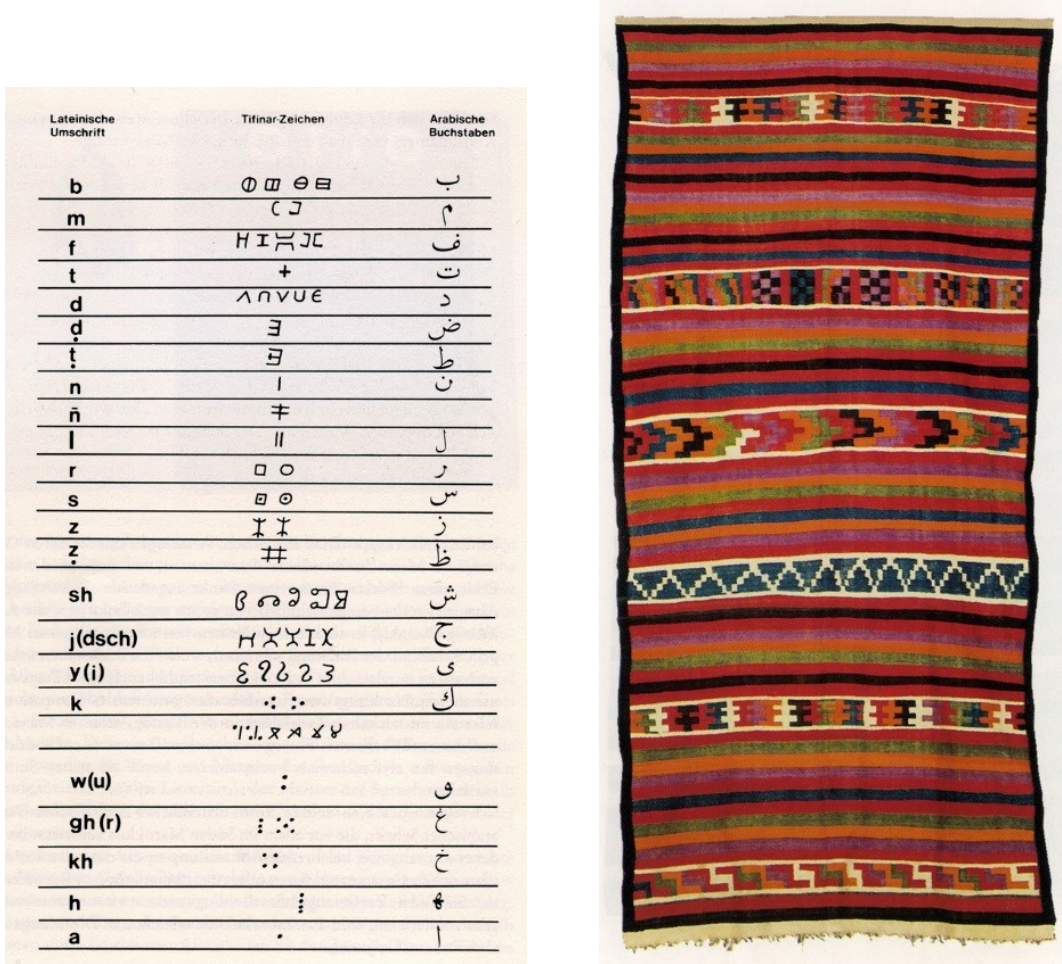

Right: Flatwoven rug klim, Central plateau, Gafsa, Tunisia, around 1950, $200 \times 300 \mathrm{~cm}$, MVD 72788

The individual, creative and often highly abstract textile works of art can be interpreted as reflections of practical everyday life and also of their makers' yearnings and desires.

However, they can be read in many different ways and arouse different thoughts and dreams in every observer. A shimmering red surface on a Rehamna knotted carpet can be associated with a striving for light and the sun; it is as if one can feel the heat and observe a sunset. The blue and black colours evoke the atmosphere of an impending thunderstorm, with the promise of refreshing rain and pleasant coolness.
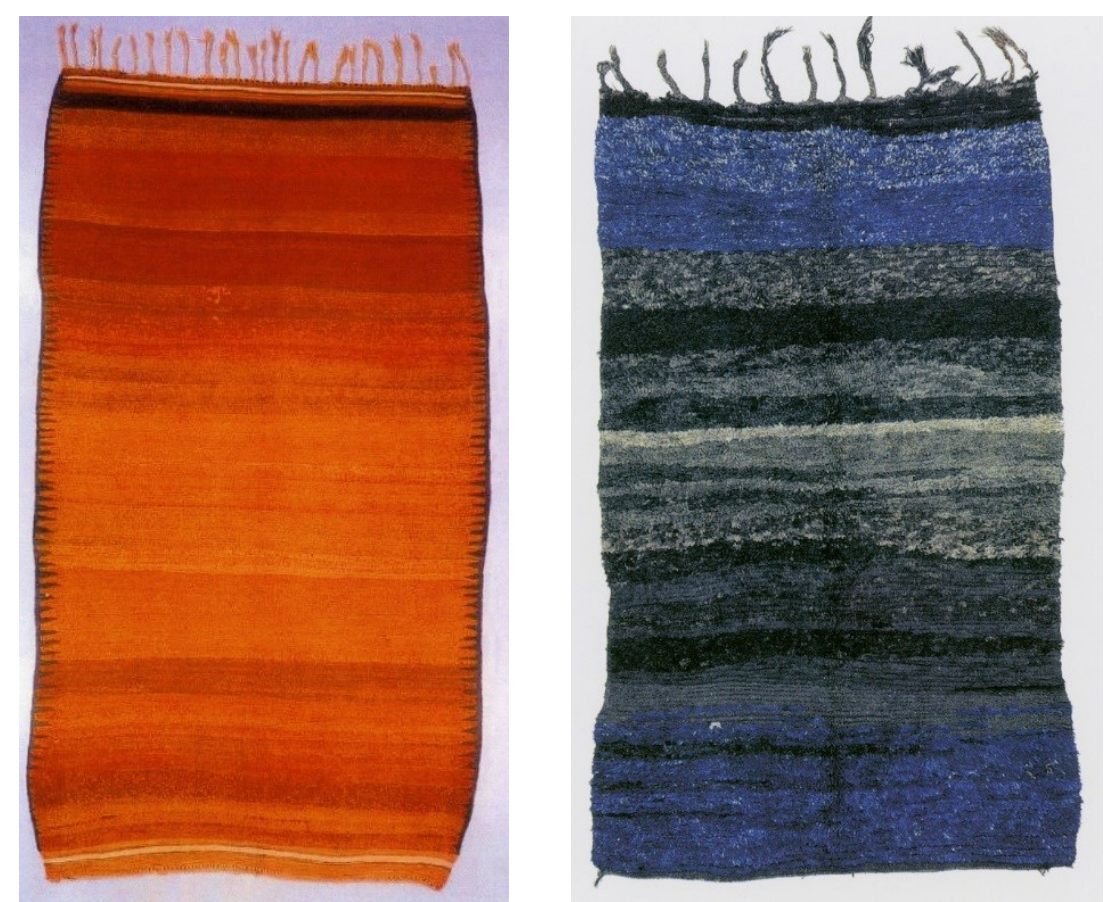

Left: Carpet, Rehamna, Plains around Marrakech, Haouz region, Morocco, 1930-40, $235 \times 410 \mathrm{~cm}$, Right: Carpet, Beni M'Guild, Middle Atlas, Morocco, 1925-35, $215 \times 130$ cm, both Collection Annette Korolnik 
All these wonderful textiles have practical functions, of course, but at the same time they are expressions of art. Especially in modified techniques and materials (recycled fabrics), which often have strong and flamboyant "wild" colours and compositions, ${ }^{9}$ they constitute innovations and reveal creative adaptation to changed conditions. As individual and expressive creations, they were discovered by textile lovers decades ago and have been collected as works of art. This has inspired many women, particularly in Morocco, to produce the same fabrics for sale as those intended for their own use. ${ }^{10}$ The value and charm of these textiles is not the rigid preservation of traditions, but rather the power of resilience and repositioning while consciously coming to terms with new influences under the rapidly changing conditions of everyday life. With unbridled creativity, the weavers, knotters and dyers from the Maghreb continue today to create textiles featuring highly formalised, abstract symbols that have a profound meaning, as they have long done in the past. It is an art consisting of symbols and colours. And they create works of art both as intuitive and as carefully thought out expressions of all dimensions of the human spirit and all shades of the human soul. The textile art produced by women in the Maghreb reflects something fundamental: the act of creation in life and in spirit, which manifests itself in constant motion and never-ending narrative.

\section{Bibliography}

Dolz, Silvia. Webgeräte und Weberei in Südtunesien. Abhandlungen und Berichte des Staatlichen Museums für Völkerkunde Dresden, 49 (1996), 47-79.

Dolz, Silvia. Produkte des textilen Frauenhandwerks aus Tunesien im kulturellen und historischen Vergleich. Abhandlungen und Berichte des Staatlichen Museums für Völkerkunde Dresden, 50 (1999), 17-59.

Khatibi, Abdelkebir and Amahan, Ali. From Sign to Image. The Moroccan Carpet. Casablanca: Lak International Edition, 1995.

Korolnik-Andersch, Annette and Korolnik, Marcel. Die Farbe Henna. Bemalte Textilien aus Süd-Marokko. Stuttgart: Arnoldsche, Art Publishers, 2002.

Maurière, Arnaud et al. Maroc, Couleurs Désert. [Genève], Clermont-Ferrand: Ethnistory, Musée Bargoin, 2014.

Tunis, Angelika. Juden und Germanen im Maghreb al-Aqsa. In: Rainer, Kurt. Marokko mon amour. Glanzvolle Textil-Tradition im Königreich Marokko. Graz: Culture and more, 2005 .

Rainer, Kurt. Marokko - mon amour. Glanzvolle Textil-Tradition im Königreich Marokko. Graz: Culture and more, 2005.

Spring, Christopher and Hudson, Julie. North African Textiles. London: British Museum Press, 1995.

\footnotetext{
${ }^{9}$ Paul Vandenbroek, Azetta - L'art des femmes berbères (Amsterdam, Bruxelles : Ludion Gand, 2000). Arnaud Maurière et al., Maroc, Couleurs Désert (Genève, Clermont-Ferrand: Ethnistory, Musée Bargoin, 2014). ${ }^{10}$ Annette Korolnik-Andersch and Marcel Korolnik, Die Farbe Henna. Bemalte Textilien aus Süd-Marokko (Stuttgart: Arnoldsche, Art Publishers, 2002), 65.
} 
Vandenbroeck, Paul. Azetta - L'art des femmes berbères. Amsterdam, Bruxelles: Ludion Gand, 2000.

Westermarck, Edward Alexander. Ritual and belief in Morocco. 2 vol., London: Macmillan and Co., 1926. 